\title{
Pengaruh Sistem Pengendalian Intern Pemerintah (SPIP) terhadap perencanaan dan pelaksanaan anggaran dana desa di Kecamatan Mentaya Hulu, Kabupaten Kotawaringin Timur
}

\section{The effect of the government internal control system (SPIP) on the planning and implementation of the village fund budget in Mentaya Hulu District, Kotawaringin Timur Regency}

\author{
Yessy Desi Kricy ${ }^{1,2,{ }^{*}, \text { Martati Simbel }^{3}}$ \\ ${ }_{1}^{1}$ Program Studi Magister Ilmu Ekonomi Program Pascasarjana Universitas Palangka Raya. Kampus UPR Tunjung Nyaho, \\ Jl. Yos Sudarso Palangka Raya, Indonesia, 73111 \\ 2 Dinas Sosial Kabupaten Katingan \\ ${ }^{3}$ Dinas Kesehatan Kabupaten Katingan \\ * Korespondensi: Yessy Desi Kricy (Email: yessydesi86@gmail.com)
}

\begin{abstract}
The purpose of this study was to analyze the influence of the Government Internal Control System (SPIP) on the planning and implementation of the village fund budget in Mentaya Hulu District, Kotawaringin Timur Regency either partially or simultaneously. The population in this study were all village and sub-district apparatus consisting of 16 villages, 1 village and 1 sub-district, with a research sample of 189 respondents. The independent variable consists of five variables, namely the control environment, risk assessment, control activities, information and communication, monitoring and the dependent variable is the planning and implementation of the village fund budget. Data were collected using a questionnaire that has been tested for validity and reliability. The data were analyzed descriptively and analyzed with multiple linear regression using the IBM SPSS 24 program. The results showed that the Government Internal Control System (SPIP), namely the control environment, risk assessment, control activities, information and communication as well as monitoring simultaneously affected planning and implementation village fund budget. SPIP has a positive effect on the implementation of the village fund budget. This means that the more implementation of SPIP will increase the implementation of the village fund budget. This indicates that Government Regulation No. 60 of 2008 has been implemented properly.
\end{abstract}

\section{Keywords}

Environmental control, risk assessment, control activities, information and communication, monitoring, planning, implementation

\section{Intisari}

Tujuan penelitian ini adalah untuk menganalisis pengaruh Sistem Pengendalian Intern Pemerintah (SPIP) terhadap perencanaan dan pelaksanaan anggaran dana desa di Kecamatan Mentaya Hulu Kabupaten Kotawaringin Timur baik secara parsial maupun simultan. Populasi dalam penelitian ini adalah seluruh perangkat desa dan kelurahan yang terdiri dari 16 desa 1 desa dan 1 kecamatan dengan sampel penelitian sebanyak 189 responden. Variabel bebas (independen) terdiri dari lima variabel yaitu lingkungan pengendalian, penilaian resiko, kegiatan pengendalian, informasi dan komunikasi, pemantauan dan variabel terikat (dependen) terdiri dari satu variabel terikat yaitu perencanaan dan pelaksanaan anggaran dana desa. Data dikumpulkan menggunakan kuesioner yang telah lolos uji validitas dan reliabilitas. Data dianalisis secara deskriptif dan analisis dengan regresi linier berganda menggunakan program IBM SPSS 24. Hasil penelitian menunjukkan bahwa Sistem Pengendalian Intern Pemerintah (SPIP), yaitu lingkungan pengendalian, penilaian resiko, kegiatan pengendalian, informasi dan komunikasi serta pemantauan berpengaruh secara simultan terhadap perencanaan dan pelaksanaan anggaran dana desa. SPIP berpengaruh positif terhadap pelaksanaan anggaran dana desa; artinya semakin diterapkannya SPIP akan meningkatkan pelaksanaan 
anggaran dana desa. Hal ini menunjukkan bahwa Peraturan Pemerintah Nomor 60 Tahun 2008 telah dilaksanakan dengan baik.

\section{Kata kunci}

Pengendalian lingkungan, penilaian risiko, kegiatan pengendalian, informasi dan komunikasi, pemantauan, perencanaan, implementasi

\section{PENDAHULUAN}

Pemberian kesempatan yang lebih besar bagi desa untuk mengurus tata pemerintahannya sendiri serta pemerataan pelaksanaan pembangunan diharapkan dapat meningkatkan kesejahteraan dan kualitas hidup masyarakat desa, sehingga permasalahan seperti kesenjangan antar wilayah, kemiskinan, dan masalah sosial budaya lainnya dapat diminimalisir. Perencanaan dan pelaksanaan anggaran dana desa merupakan langkah awal pemerintah desa untuk menyelenggarakan pemerintahan di desa.

Menurut Peraturan Pemerintah No 60 tahun 2014, dana desa adalah dana yang bersumber dari anggaran pendapatan dan belanja negara yang diperuntukan bagi desa dan desa adat yang ditransfer malalui anggaran pendapatan belanja daerah kabupaten/kota dan digunakan untuk membiayai penyelenggaraan pemerintahan, pembangunan, serta pemberdayaan masyarakat dan kemasyarakatan.

Dalam Peraturan Menteri Desa No. 5 tahun 2015 disebutkan bahwa penggunaan dana desa untuk pembangunan desa harus memenuhi empat prioritas utama. Keempat prioritas utama penggunaan dana desa yaitu: pemenuhan kebutuhan dasar, pembangunan sarana dan prasarana, pengembangan potensi ekonomi dan pemanfaatan sumber daya alam dan lingkungan secara berkelanjutan.

Peraturan Pemerintah Nomor 60 tahun 2008 tentang sistem pengendalian intern pemerintah (SPIP) menyebutkan bahwa pengelolaan keuangan daerah yang lebih akuntabel dan transparan dapat dicapai jika seluruh jajaran pimpinan di daerah menyelenggarakan keseluruhan kegiatan pengendalian mulai dari perencanaan, pelaksanaan, pengawasan, sampai dengan pertanggungjawaban secara tertib, terkendali, efektif dan efisien. Untuk itu dibutuhkan suatu sistem yang menjamin bahwa penyelenggaraan kegiatan pada suatu instansi pemerintah dapat mencapai tujuannya secara efektif dan efisien serta melaporkan pengelolaan keuangan daerah secara andal, mengamankan aset daerah, mendorong ketaatan terhadap peraturan perundang-undangan.

Alasan atau latar belakang diterbitkannya Peraturan Pemerintah Nomor 60 tahun 2008 tentang Sistem Pengendalian Intern Pemerintah (SPIP) adalah sebagai petunjuk pelaksanaan dari paket reformasi keuangan negara menuju good governance atau tata kelola yang baik dan good geverment. Sistem Pengendalian Intern Pemerintah diadopsi dari konsep internal control yang dikeluarkan oleh COSO (the committee of sponsoring organizations of the treadway commission) yang berusaha meningkatkan kinerja dan tata kelola organisasinya menggunakan manajemen risiko terpadu (enterprise risk management), pengendalian intern (internal control) dan pencegahan kecurangan (fraud detterence). COSO memiliki prinsip dasar manajemen risiko dan pengendalian internal yang baik yang diperlukan untuk keberhasilan jangka panjang organisasi (Pamungkas, 2019).

Unsur-unsur yang ada dalam SPIP mengacu pada unsur SPI yang telah dipraktekkan di lingkungan pemerintahan di berbagai negara yang meliputi lingkungan pengendalian, penilaian resiko, kegiatan pengendalian, informasi dan komunikasi, pemantauan pengendalian intern (Martini et al., 2019).

Perencanaan keuangan desa meliputi penyusunan Rencana Pembangunan Jangka Menengah Desa (RPJM Desa), penyusunan Rencana Kerja Pemerintah Desa (RKP Desa) sedangkan Penganggaran Keuangan Desa meliputi penyusunan Anggaran Pendapatan dan Belanja Desa (APB Desa). Pelaksanaan anggaran desa yang sudah ditetapkan sebelumnya timbul transaksi penerimaan dan pengeluaran desa. Semua penerimaan dan pengeluaran desa dalam rangka pelaksanaan kewenangan desa dilaksanakan melalui rekening kas desa. Jika desa yang belum memiliki layanan perbankan di wilayahnya maka pengaturannya ditetapkan oleh Pemerintah Kabupaten/Kota. Semua penerimaan dan pengeluaran desa harus didukung oleh bukti yang lengkap dan sah.

Sistem pengendalian intern pemerintah berfungsi sebagai pedoman penyelenggaraan sistem pengendalian intern. Salah satu unsur SPIP adalah lingkungan pengendalian menetapkan corak suatu organisasi yang dapat mempengaruhi kesadaran pengendalian orangorangnya. Lingkungan pengendalian sebagai dasar semua komponen pengendalian intern, menyediakan disiplin dan struktur. Sehubungan dengan fenomena yang terkait dengan lingkungan pengendalian pada pemerintah desa di Kecamatan Mentaya Hulu masih belum optimalnya komitmen dari pimpinan untuk menerapkan SPIP sesuai ketentuan indikator-indikator yang berlaku. Padahal lingkungan pengendalian sebagai soft control yang mendapatkan porsi terbesar dalam membangun etika, moral, integritas, kejujuran, disiplin, komitmen dari para 
pelaksana kegiatan untuk dapat melaksanakan tata kelola yang didukung dengan hard control yang baik.

Evaluasi tingkat perencanaan dan pelaksanaan anggaran dana desa dari beberapa daerah otonom menunjukan masih terdapat beberapa kegagalan dalam pelaksanaan anggaran. Hal tersebut disampaikan oleh kepala Badan Pengawas Keuangan dan Pembangunan (BPKP) Provinsi Kalimantan Tengah, dalam arti bahwa banyak hal yang perlu dibenahi terkait dengan perencanaan dan pelaksanaan anggaran dana. Fenomena yang terjadi saat ini, pemerintah Kabupaten Kotawaringin Timur mengalokasikan dana desa sebesar Rp. 252.192.374.800 untuk 168 desa yang tersebar di 17 kecamatan. Sementara itu, pengelolaan anggaran desa masih menjadi kendala yang banyak dihadapi desa di Kotawaringin Timur. Bahkan tahun lalu ada desa yang hanya menggunakan anggaran untuk gaji, sedangkan untuk program pembangunan tidak ada sama sekali, padahal setiap desa mengelola anggaran rata-rata di atas Rp 1 miliar (Norjani, 2019).

Hindriani et al. (2012) menyatakan pelaksanaan sistem pengendalian intern pemerintah di dinas kesehatan terbatas pada internalisasi SPIP ke dalam seluruh proses kerja di organisasi, unsur lingkungan pengendalian sebagai variabel independen, dengan telah diterapkannya sebagai soft control dan mendapatkan porsi terbesar untuk membangun etika, moral, integritas, kejujuran, disiplin, kompetensi, komitmen dari para pelaksana kegiatan untuk dapat melaksanakan tata kelola yang didukung dengan hard control yang baik. Di sini masih kurang adanya komitmen dari kepala dinas untuk menerapkan SPIP sesuai dengan ketentuan yang berlaku. Berbeda halnya dengan penelitian Herawati (2014), bahwa lingkungan pengendalian berpengaruh secara signifikan terhadap kualitas laporan keuangan. Organisasi perangkat desa harus meningkatkan lingkungan pengendalian dengan memperhatikan komitmen terhadap kompetensi dan memiliki prosedur yang efektif untuk memantau hasil kewenangan dan tanggung jawab yang didelegasikan. Mutmainah dan Pramuka (2017) menunjukkan bahwa sistem pengendalian intern pemerintah tidak berpengaruh signifikan terhadap pengelolaan dana desa. Sementara itu Atmadja dan Saputra (2017) menyimpulkan bahwa sistem pengendalian internal berpengaruh terhadap pencegahan fraud dalam pengelolaan dana desa.

Pemerintah desa di Kecamatan Mentaya Hulu diberi tugas mengatur dan mengurus urusan pemerintahan, kepentingan masyarakat setempat berdasarkan prakarsa masyarakat. Pelaksanaan kewenangan desa tersebut sudah pasti memerlukan pengelolaan keuangan desa yang baik, meliputi perencanaan, pelaksanaan, penatausahaan, pelaporan, dan pertanggungjawaban keuangan desa. Bertolak dari latar belakang di atas, penelitian ini bertujuan menganalisis pengaruh sistem pengendalian intern pemerintah terhadap perencanaan dan pelaksanaan anggaran dana desa di Kecamatan Mentaya Hulu, Kabupaten Kotawaringin Timur.

\section{METODOLOGI}

\subsection{Populasi, Sampel dan Data}

Populasi dalam penelitian ini adalah seluruh aparatur pemerintah desa di Kecamatan Mentaya Hulu Kabupaten Kotawaringin Timur. Teknik pengambilan sampel yang digunakan dalam penelitian ini adalah purposive sampling. Sampel yang digunakan 189 responden terdiri dari kepala desa, perangkat desa dan tim pengelola dana desa serta tokoh masyarakat yang berhubungan dengan pengelolaan dana.

Jenis data yang digunakan adalah data kuantitatif yang diperoleh langsung dari responden dengan menggunakan kuesioner. Kuisioner yang digunakan adalah kuisioner tertutup, dengan Skala Likert 1-5. Data yang digunakan adalah hasil dari kuisioner (data primer) sehingga harus dilakukan uji validitas, dengan cara menghitung korelasi dari masing-masing pernyataan dengan skor total. Taraf signifikan yang digunakan alpha $(\alpha)=5 \%$ apabila $r$ hitung $>$ r tabel maka dikatakan valid (Safitri, 2015).

\subsection{Analisis Statistik Deskriptif dan Analisis Regresi Linear Berganda}

Dalam penelitian ini, digunakan variabel dependen perencanaan dan pelaksanaan anggaran dana desa variabel independen lingkungan pengendalian, penilaian resiko, kegiatan pengendalian, informasi dan komunikasi dan pemantauan. Persamaan regresi yang digunakan disajikan pada Gambar 1.

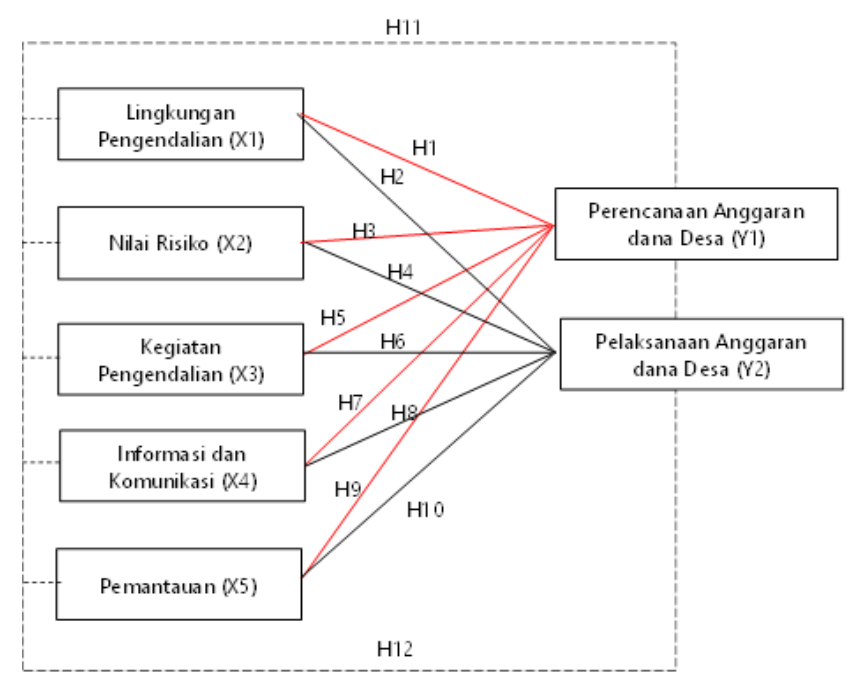

Secara Parsial

Secara Simultan

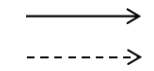

Gambar 1 Persamaan regresi penelitian

\subsection{Hipotesis Penelitian}

Terdapat 12 hipotesis penelitian, yaitu:

$\mathrm{H} 1-\mathrm{a}$ : Lingkungan pengendalian berpengaruh terhadap perencanaan anggaran dana desa.

$\mathrm{H} 2-\mathrm{b}$ : Lingkungan pengendalian berpengaruh terhadap pelaksanaan anggaran dana desa.

H3-a : Penilaian Resiko berpengaruh terhadap 
perencanaan anggaran dana desa.

H4-b : Penilaian Resiko berpengaruh terhadap pelaksanaan anggaran dana desa

$\mathrm{H} 5-\mathrm{a}$ : Kegiatan pengendalian berpengaruh terhadap perencanaan anggaran dana desa.

H6-b : Kegiatan pengendalian berpengaruh terhadap pelaksanaan anggaran dana desa.

H7-a : Informasi dan Komunikasi berpengaruh terhadap perencanaan anggaran dana desa.

H8-b : Informasi dan Komunikasi berpengaruh terhadap pelaksanaan anggaran dana desa.

H9-a : Pemantauan berpengaruh terhadap perencanaan dan pelaksanaan anggaran dana desa

H10-b : Pemantauan berpengaruh terhadap perencanaan dan pelaksanaan anggaran dana desa

$\mathrm{H} 11-\mathrm{a}$ : Lingkungan pengendalian, Penilaian Resiko, Kegiatan pengendalian, Informasi dan Komunikasi serta Pemantauan secara simultan berpengaruh terhadap perencanaan anggaran dana desa.

H12-b : Lingkungan pengendalian, Penilaian Resiko, Kegiatan pengendalian, Informasi dan Komunikasi serta Pemantauan secara simultan berpengaruh terhadap pelaksanaan anggaran dana desa.

\subsection{Definisi Operasional Variabel Beas dan Variabel Tidak Bebas Penelitian}

- Varibel Tidak Bebas

1. Perencanaan anggaran dana desa (Y1), Perencanaan (planning) adalah pemilihan atau penetapan organisasi dan penentuan strategi, kebijaksanaan, proyek, program, prosedur, metode, sistem, anggaran dan standar yan dibutuhakan untuk mencapai tujuan.

2. Pelaksanaan anggaran dana desa (Y2), Pelaksanaan adalah suatu tindakan atau pelaksanaan dari sebuah perencanaan yang sudah disusun secara matang dan terperinci, implementasi biasanya dilakukan setelah perencanaan dianggap siap (Ratag et al., 2021)

- Varibel Bebas

1. Lingkungan pengendalian (X1), kondisi dalam instansi pemerintah yang mempengaruhi efektivitas pengendalian intern. Pemimpin instansi pemerintah wajib menciptakan dan memelihara lingkungan pengendalian yang menimbulkan perilaku positif dan kondusif untuk penerapan sistem pengendalian intern dalam lingkungan kerjanya.

2. Penilaian resiko (X2), penilaian resiko adalah kegiatan penilaian atas kemungkinan terjadinya sesuatu yang mengancam pencapaian tujuan dan sasaran instansi pemerintah.

3. Kegiatan pengendalian (X3), tindakan yang diperlukan untuk mengatasi risiko serta penetapan dan pelaksanaan kebijakan dan prosedur untuk memastikan bahwa tindakan mengatasi resiko telah dilaksanakan secara efektif.

4. Informasi dan komunikasi (X4), data yang telah diolah yang dapat digunakan untuk pengambilan keputusan dalam rangka penyelenggaraan tugas dan fungsi instansi pemerintah. Komunikasi sendiri memiliki pengertian sebagai proses penyampaian pesan atau informasi dengan menggunakan simbol atau lambang tertentu baik secara langsung maupun tidak langsung untuk mendapatkan umpan balik.

5. Pemantauan (X5), proses penilaian atas mutu kerja sistem pengendalian intern dan proses yang memberikan keyakinan bahwa temuan audit dan evaluasi lainya segera ditindaklanjuti.

\subsection{Pengujian Hipotesis}

Uji Signifikansi Parameter Individual (Uji Statistik t). Jika nilai sign $\mathrm{t}>0,05$ maka Ha ditolak namun jika nilai sign $\mathrm{t}<$ 0,05 maka Ha diterima dan berarti terdapat pengaruh yang signifikan antara variabel independen dengan variabel dependen (Ghozali, 2016). Uji Signifikansi Simultan (Uji Statistik F). Jika nilai signifikan lebih kecil dari 0,05 maka $\mathrm{H}_{0}$ ditolak dan $\mathrm{H}_{\mathrm{a}}$ diterima. Sebaliknya, jika nilai signifikan lebih besar dari 0,05 maka $\mathrm{H}_{0}$ diterima dan $\mathrm{H}_{\mathrm{a}}$ ditolak, hal ini berarti bahwa semua variabel independen tidak mempunyai pengaruh secara bersamasama terhadap variabel dependen (Ghozali, 2016). Uji Koefisien Determinasi $(R)^{2}$. Jika dalam uji empiris didapat nilai adjusted $R^{2}$ negatif, maka nilai adjusted $R^{2}$ dianggap bernilai nol. Secara matematis jika nilai $R^{2}=1$, maka adjusted $R^{2}=R^{2}$ yaitu sama dengan 1 . Sedangkan jika nilai $R^{2}=0$, maka adjusted $R^{2}=(1-k) /(n-k)$. Jika $k>1$, maka adjusted $R^{2}$ akan bernilai negatif.

\section{HASIL}

\subsection{Analisis Regresi Linear Berganda}

Analisis regresi linear berganda digunakan untuk meramalkan bagan suatu keadaan yaitu naik turunnya variabel independen, bila dua atau lebih variabel independen sebagai faktor prediktor dimanipulasi (dinaik turunkan nilainya). Analisis ini akan dilakukan jika jumlah variabel independen minimal dua (Hartono, 2017). Hasil uji regresi linear berganda untuk variabel perencanaan (Y1) anggaran dana desa ditunjukkan pada Tabel 1.

Berdasarkan Tabel 1 diperoleh persamaaan regresi:

$P R N=\alpha+\beta 1 L P+\beta 2 P R+\beta 3 K P+\beta 4 I K+\beta 5 P+e$.

$P R N=5,898+0,139 L P+-0,152 P R+0,163 K P+-0,117 \mathrm{IK}+$ $-0,124 \mathrm{P}+\mathrm{e}$

Berdasarkan persamaan regresi linier berganda untuk variabel dependen perencanaan anggaran dana desa diatas maka dapat dijelaskan sebagai berikut:

1. Nilai konstanta diperoleh sebesar 5,898 yang berarti jika variabel independen yaitu lingkungan pengendalian, penilaian resiko, kegiatan pengendalian, informasi dan komunikasi, pemantauan tidak ada maka nilai variabel dependen yaitu perencanaan anggaran dana desa adalah sebesar 5,898. 
Tabel 1 Analisis regresi berganda (Y1)

\begin{tabular}{|c|c|c|c|c|c|c|}
\hline \multicolumn{7}{|c|}{ Coefficients $^{a}$} \\
\hline \multirow{2}{*}{ Model } & & \multicolumn{2}{|c|}{ Unstandardized Coefficients } & \multirow{2}{*}{$\begin{array}{c}\text { Standardized } \\
\text { Coefficients } \\
\text { Beta }\end{array}$} & \multirow{2}{*}{$\mathbf{T}$} & \multirow{2}{*}{ Sig } \\
\hline & & B & Std.error & & & \\
\hline \multirow[t]{6}{*}{1} & (Constanta & 5,898 &, 848 & & 6,956 &, 000 \\
\hline & Total_X1 & 139 & ,028 & ,381 & 4,907 &, 000 \\
\hline & Total_ X2 &,- 152 &, 038 &,- 235 & $-3,978$ &, 000 \\
\hline & Total_X3 & 163 & 019 & 611 & 8,794 &, 000 \\
\hline & Total_ X4 &,- 177 &, 037 &,- 170 & $-3,167$ &, 002 \\
\hline & Total_ X5 &,- 124 & ,039 &,- 146 & $-3,191$ & ,002 \\
\hline
\end{tabular}

a. Dependent Variable: Total_Y1

2. Koefisien regresi lingkungan pengendalian pada persamaan di atas diperoleh nilai sebesar 0,139. Hal ini berarti bahwa setiap terjadinya kenaikan satu persen lingkungan pengendalian maka akan meningkatkan perencanaan anggaran dana desa sebesar 13,9\% dengan asumsi variabel indevenden lainya konstan.

3. Koefisien regresi penilaian resiko pada persamaan di atas diperoleh nilai sebesar -0,152. Hal ini berarti bahwa setiap terjadinya kenaikan satu persen penilaian resiko maka akan meningkatkan perencanaan anggaran dana desa sebesar 15,2\% dengan asumsi variabel indevenden lainya konstan.

4. Koefisien regresi kegiatan pengendalian pada persamaan di atas diperoleh nilai sebesar 0,163. Hal ini berarti bahwa setiap terjadinya kenaikan satu persen kegiatan pengendalian maka akan meningkatkan perencanaan anggaran dana desa sebesar 16,3\% dengan asumsi variabel indevenden lainya konstan.

5. Koefisien regresi informasi dan komunikasi pada persamaan di atas diperoleh nilai sebesar $-0,117$. Hal ini berarti bahwa setiap terjadinya kenaikan satu persen informasi dan komunikasi maka akan meningkatkan perencanaan anggaran dana desa sebesar 11,7\% dengan asumsi variabel indevenden lainya konstan.
6. Koefisien regresi pemantauan pada persamaan di atas diperoleh nilai sebesar $-0,124$. Hal ini berarti bahwa setiap terjadinya kenaikan satu persen pemantauan maka akan meningkatkan perencanaan anggaran dana desa sebesar $12,4 \%$ dengan asumsi variabel indevenden lainya konstan.

Hasil uji regresi linear berganda untuk variabel pelaksanaan (Y2) anggaran dana desa ditunjukkan pada Tabel 2.

Berdasarkan Tabel 2 diperoleh persamaan regresi sebagi berikut:

$$
\begin{aligned}
P L K= & \alpha+\beta 1 L P+\beta 2 P R+\beta 3 K P+\beta 4 I K+\beta 5 P+e . \\
P L K= & 5,343+0,144 L P+-0,146 P R+0,168 K P+- \\
& 0,126 I K+-0,122 P+e
\end{aligned}
$$

Berdasarkan persamaan regresi linier berganda untuk variabel pelaksanaan anggaran dana desa diatas maka dapat dijelaskan sebagai berikut:

1. Pada persamaan di atas nilai konstanta diperoleh sebesar 5,343 yang berarti jika variabel independen yaitu lingkungan pengendalian, penilaian resiko, kegiatan pengendalian, informasi dan komunikasi, pemantauan tidak ada maka nilai variabel dependen yaitu pelaksanaan anggaran dana desa adalah sebesar

\begin{tabular}{|c|c|c|c|c|c|c|}
\hline \multicolumn{7}{|c|}{ Coefficients $^{a}$} \\
\hline \multirow{2}{*}{ Model } & & \multicolumn{2}{|c|}{ Unstandardized Coefficients } & \multirow{2}{*}{$\begin{array}{c}\text { Standardized } \\
\text { Coefficients } \\
\text { Beta }\end{array}$} & \multirow{2}{*}{$\mathbf{T}$} & \multirow{2}{*}{ Sig. } \\
\hline & & B & Std.error & & & \\
\hline \multirow[t]{6}{*}{1} & (Constanta & 5,434 &, 815 & & 6,668 &, 000 \\
\hline & Total_ X1 &, 144 & 027 & ,395 & 5,308 &, 000 \\
\hline & Total_X2 &,- 146 &, 037 &,- 225 & $-3,989$ &, 000 \\
\hline & Total_ X3 & , 168 & 018 & ,624 & 9,399 &, 000 \\
\hline & Total_ X4 &,- 126 &, 036 &,- 181 & $-3,530$ &, 001 \\
\hline & Total_ X5 &,- 122 &, 037 &,- 143 & $-3,266$ &, 001 \\
\hline
\end{tabular}
5,343 .

Tabel 2 Analisis regresi berganda (Y2)

a. Dependent Variable: Total_Y2 
2. Koefisien regresi lingkungan pengendalian pada persamaan di atas diperoleh nilai sebesar 0,144. Hal ini berarti bahwa setiap terjadinya kenaikan satu persen Lingkungan pengendalian maka akan meningkatkan pelaksanaan anggaran dana desa sebesar 14,4\% dengan asumsi variabel independen lainya konstan.

3. Koefisien regresi penilaian resiko pada persamaan di atas diperoleh nilai sebesar -0,146. Hal ini berarti bahwa setiap terjadinya kenaikan satu persen penilaian resiko maka akan meningkatkan pelaksanaan anggaran dana desa sebesar $14,6 \%$ dengan asumsi variabel indevenden lainya konstan.

4. Koefisien regresi kegiatan pengendalian pada persamaan di atas diperoleh nilai sebesar 0,168. Hal ini berarti bahwa setiap terjadinya kenaikan satu persen kegiatan pengendalian maka akan meningkatkan pelaksanaan anggaran dana desa sebesar 16,8\% dengan asumsi variabel indevenden lainya konstan.

5. Koefisien regresi informasi dan komunikasi pada persamaan di atas diperoleh nilai sebesar -0,126. Hal ini berarti bahwa setiap terjadinya kenaikan satu persen informasi dan komunikasi maka akan meningkatkan pelaksanaan anggaran dana desa sebesar $12,6 \%$ dengan asumsi variabel indevenden lainya konstan.

6. Koefisien regresi pemantauan pada persamaan di atas diperoleh nilai sebesar $-0,122$. Hal ini berarti bahwa setiap terjadinya kenaikan satu persen pemantauan maka akan meningkatkan pelaksanaan anggaran dana desa sebesar 12,2\% dengan asumsi variabel indevenden lainya konstan.

\subsection{Uji Parsial (Uji Hipotesis)}

Pengujian hipotesis dalam penelitian ini bertujuan untuk menguji bagaimana Lingkungan pengendalian, Penilaian Resiko, Kegiatan Pengendalian, Informasi dan Komunikasi serta Pemantauan berpengaruh terhadap Perencanaan dan Pelaksanaan Anggaran Dana Desa. Hasil Uji Hipotesis Variabel Dependen Perencanaan Anggaran Dana Desa (Y1) disajikan pada Tabel 3. Sementara itu hasil Uji Hipotesis Variabel Dependen Pelaksanaan Anggaran Dana Desa (Y2) disajikan pada Tabel 4.

Berdasarkan hasil dari $T_{\text {hitung }}$ dan signifikansi uji statistik t pada Tabel 3 dan Tabel 4 dapat disimpulkan sebagai berikut:

1. Pengaruh secara parsial lingkungan pengendalian terhadap perencanaan dan pelaksanaan anggaran dana desa.

a) Uji hipotesis secara parsial $\mathrm{H} 1$-a adalah lingkungan pengendalian berpengaruh terhadap perencanaan anggaran dana desa. Berdasarkan Tabel 3, koefisien regresi variabel Lingkungan pengendalian sebesar 4,907 dengan nilai signifikansi 0,000. Nilai tersebut signifikan pada tingkat signifikansi $=5 \%$; karena

Tabel 3 Uji T (Y1)

\begin{tabular}{|c|c|c|c|c|c|c|}
\hline \multicolumn{7}{|c|}{ Coefficients $^{a}$} \\
\hline \multirow{2}{*}{ Model } & & \multicolumn{2}{|c|}{ Unstandardized Coefficients } & \multirow{2}{*}{$\begin{array}{c}\text { Standardized } \\
\text { Coefficients } \\
\text { Beta }\end{array}$} & \multirow{2}{*}{$\mathbf{T}$} & \multirow{2}{*}{ Sig. } \\
\hline & & B & Std.error & & & \\
\hline \multirow[t]{6}{*}{1} & (Constanta & 5,898 &, 848 & & 6,956 & ,000 \\
\hline & Total_ X1 & 139 & ,028 & ,381 & 4,907 & ,000 \\
\hline & Total_X2 &,- 152 & ,038 &,- 235 & $-3,978$ & ,000 \\
\hline & Total_X3 &, 163 & ,019 &, 611 & 8,794 &, 000 \\
\hline & Total_X4 &,- 177 & 037 &,- 170 & $-3,167$ & ,002 \\
\hline & Total_ X5 &,- 124 &, 039 &,- 146 & $-3,191$ & ,002 \\
\hline
\end{tabular}

a. Dependent Variable: Total_Y1

Tabel 4 Uji T (Y2)

\begin{tabular}{|c|c|c|c|c|c|c|}
\hline \multicolumn{7}{|c|}{ Coefficients $^{a}$} \\
\hline \multirow{2}{*}{ Model } & & \multicolumn{2}{|c|}{ Unstandardized Coefficients } & \multirow{2}{*}{$\begin{array}{c}\text { Standardized } \\
\text { Coefficients } \\
\text { Beta } \\
\end{array}$} & \multirow{2}{*}{$\mathbf{t}$} & \multirow{2}{*}{ Sig. } \\
\hline & & B & Std.error & & & \\
\hline \multirow[t]{6}{*}{1} & (Constanta & 5,434 & ,815 & & 6,668 &, 000 \\
\hline & Total_ X1 &, 144 & 027 & ,395 & 5,308 &, 000 \\
\hline & Total_X2 &,- 146 & ,037 &,- 225 & $-3,989$ &, 000 \\
\hline & Total_X3 &, 168 & ,018 &, 624 & 9,399 &, 000 \\
\hline & Total_ X4 &,- 126 &, 036 &,- 181 & $-3,530$ & 001 \\
\hline & Total_ X5 &,- 122 &, 037 &,- 143 & $-3,266$ & 001 \\
\hline
\end{tabular}

a. Dependent Variable: Total_Y2 
signifikansi 0,000 < 0,05 yang berarti lingkungan pengendalian berpengaruh terhadap perencanaan anggaran dana desa sehingga $\mathrm{H} 1$-a penelitian ini diterima.

b) Uji hipotesis secara parsial $\mathrm{H} 2-\mathrm{b}$ adalah lingkungan pengendalian berpengaruh terhadap pelaksanaan anggaran dana desa. Berdasarkan Tabel 4, koefisien regresi variabel lingkungan pengendalian sebesar 5,308 dengan nilai signifikansi 0,000. Nilai tersebut signifikan pada tingkat signifikansi $=5 \%$; karena signifikansi $0,000<0,05$ yang berarti lingkungan pengendalian berpengaruh terhadap pelaksanaan anggaran dana desa sehingga $\mathrm{H} 2-\mathrm{b}$ penelitian ini diterima.

2. Pengaruh secara parsial penilaian resiko terhadap perencanaan dan pelaksanaan anggaran dana desa.

a) Uji hipotesis secara parsial H3-a adalah Penilaian resiko berpengaruh terhadap perencanaan anggaran dana desa. Berdasarkan Tabel 3, koefisien regresi variabel penilaian resiko sebesar $-3,978$ dengan nilai signifikansi 0,000. Nilai tersebut signifikan pada tingkat signifikansi $=5 \%$; karena signifikansi $0,000<0,05$ yang berarti Penilaian Resiko berpengaruh terhadap perencanaan anggaran dana desa sehingga $\mathrm{H} 3-\mathrm{a}$ penelitian ini diterima.

b) Uji hipotesis secara parsial $\mathrm{H} 4-\mathrm{b}$ adalah penilaian resiko berpengaruh terhadap pelaksanaan anggaran dana desa. Berdasarkan Tabel 4, koefisien regresi variabel Penilaian Resiko sebesar -3,989 dengan nilai signifikansi 0,000 . Nilai tersebut signifikan pada tingkat signifikansi $=5 \%$; karena signifikansi $0,000<$ 0,05 yang berarti penilaian resiko berpengaruh terhadap pelaksanaan anggaran dana desa sehingga $\mathrm{H} 4-\mathrm{b}$ penelitian ini diterima.

3. Pengaruh secara parsial kegiatan pengendalian terhadap perencanaan dan pelaksanaan anggaran dana desa.

a) Uji hipotesis secara parsial $\mathrm{H} 5$-a adalah kegiatan pengendalian berpengaruh terhadap perencanaan anggaran dana desa. Berdasarkan Tabel 3, koefisien regresi variabel kegiatan pengendalian sebesar 8,794 dengan nilai signifikansi 0,000 . Nilai tersebut signifikan pada tingkat signifikansi $=5 \%$; karena signifikansi $0,000<0,05$ yang berarti kegiatan pengendalian berpengaruh terhadap perencanaan anggaran dana desa sehingga $\mathrm{H} 5$-a penelitian ini diterima.

b) Uji hipotesis secara parsial $\mathrm{H6}$-b adalah kegiatan pengendalian berpengaruh terhadap pelaksanaan anggaran dana desa. Berdasarkan Tabel 4, koefisien regresi variabel Kegiatan Pengendalian sebesar 9,399 dengan nilai signifikansi 0,000. Nilai tersebut signifikan pada tingkat signifikansi $=5 \%$; karena signifikansi $0,000<0,05$, maka kegiatan pengendalian berpengaruh terhadap pelaksanaan anggaran dana desa sehingga $\mathrm{H} 6-\mathrm{b}$ penelitian ini diterima.
4. Pengaruh secara parsial informasi dan komunikasi terhadap perencanaan dan pelaksanaan anggaran dana desa.

a) Uji hipotesis secara parsial $\mathrm{H} 7$-a adalah informasi dan komunikasi berpengaruh terhadap perencanaan anggaran dana desa. Berdasarkan Tabel 3, koefisien regresi variabel informasi dan komunikasi sebesar 3,167 dengan nilai signifikansi 0,002. Nilai tersebut signifikan pada tingkat signifikansi $=5 \%$; karena signifikansi 0,002<0,05 yang berarti informasi dan komunikasi berpengaruh terhadap perencanaan anggaran dana desa sehingga $\mathrm{H} 7-\mathrm{a}$ penelitian ini diterima.

b) Uji hipotesis secara parsial H8-b adalah informasi dan komunikasi berpengaruh terhadap pelaksanaan anggaran dana desa. Berdasarkan Tabel 4, koefisien regresi variabel informasi dan komunikasi sebesar 3,530 dengan nilai signifikansi 0,001 . Nilai tersebut signifikan pada tingkat signifikansi $=5 \%$; karena signifikansi 0,001<0,05 yang berarti informasi dan komunikasi berpengaruh terhadap pelaksanaan anggaran dana desa sehingga $\mathrm{H} 8 \mathrm{-b}$ penelitian ini diterima.

5. Pengaruh secara parsial pemantauan terhadap perencanaan dan pelaksanaan anggaran dana desa.

a) Uji hipotesis secara parsial $\mathrm{H} 9$-a adalah pemantauan berpengaruh terhadap perencanaan anggaran dana desa. Berdasarkan Tabel 3, koefisien regresi variabel pemantauan sebesar -3,191 dengan nilai signifikansi 0,002. Nilai tersebut signifikan pada tingkat signifikansi $=5 \%$; karena signifikansi 0,002 $<0,05$ yang berarti pemantauan berpengaruh terhadap perencanaan anggaran dana desa sehingga H9-a penelitian ini diterima.

b) Uji hipotesis secara parsial $\mathrm{H} 10-\mathrm{b}$ adalah pemantauan berpengaruh terhadap pelaksanaan anggaran dana desa. Berdasarkan Tabel 4, koefisien regresi variabel Pemantauan sebesar -3,266 dengan nilai signifikansi 0,001 . Nilai tersebut signifikan pada tingkat signifikansi $=5 \%$; karena signifikansi 0,001 < 0,05 yang berarti pemantauan berpengaruh terhadap pelaksanaan anggaran dana desa sehingga $\mathrm{H} 10-\mathrm{b}$ penelitian ini diterima.

\subsection{Uji Simultan (Uji F)}

Uji F atau dikenal dengan Uji Simultan bertujuan untuk melihat seberapa besar pengaruh semua variabel bebas (independen) dalam hal ini Lingkungan Pengendalian, Penilaian Resiko, Kegiatan Pengendalian, Informasi dan Komunikasi serta Pemantauan secara bersama-sama berpengaruh terhadap variabel terikatnya (dependen). Hasil Uji F (Uji Simultan) variabel dependen Perencanaan Anggaran Dana Desa (Y1) disajikan pada Tabel 5. sementara itu hasil Uji F (Uji Simultan) variabel Dependen Pelaksanaan Anggaran Dana Desa (Y2) disajikan pada Tabel 6. 
Tabel 5 Hasil uji F (Y1)

\begin{tabular}{|c|c|c|c|c|c|c|}
\hline \multicolumn{7}{|c|}{ ANOVA $^{a}$} \\
\hline & Model & Sum of Squares & df & Mean Square & $\mathbf{F}$ & Sig \\
\hline \multirow[t]{3}{*}{1} & Regression & 238,697 & 5 & 47,739 & 60,451 &, $000^{b}$ \\
\hline & Residual & 144,519 & 183 & 790 & & \\
\hline & Total & 383,217 & 188 & & & \\
\hline
\end{tabular}

a. Dependent Variable: Total_Y1

b. Predictors: (Constant), Total_X5, Total_X2, Total_X4, Total_X3, Total_X1

Tabel 6 Hasil uji F (Y2)

\begin{tabular}{ccccccc}
\hline \multicolumn{1}{c}{} & \multicolumn{1}{c}{ ANOVA $^{\text {a }}$} & & \\
\hline & Model & Sum of Squares & df & Mean Square & F & Sig \\
\hline 1 & Regression & 253,461 & 5 & 50,692 & 69,493 &, $000^{\mathrm{b}}$ \\
& Residual & 133,491 & 183 & & \\
& Total & 386,952 & 188 & & \\
\hline
\end{tabular}

a. Dependent Variable: Total_Y1

b. Predictors: (Constant), Total_X5, Total_X2, Total_X4, Total_X3, Total_X1

Hasil uji F memberikan informasi sebagai berikut:

1. Uji F (uji simultan) variabel dependen perencanaan anggaran dana desa.

Tabel 5 menunjukan nilai $F$ hitung sebesar 60,451 dengan nilai signifikansi sebesar 0,000 dan lebih kecil daripada tingkat signifikansi yang digunakan pada penelitian ini yaitu $5 \%$ atau 0,05 , maka dapat disimpulkan bahwa lingkungan pengendalian, penilaian resiko, kegiatan pengendalian, informasi dan komunikasi serta pemantauan secara simultan berpengaruh signifikan terhadap perencanaan anggaran dana desa.

2. Uji $F$ (uji simultan) variabel dependen pelaksanaan anggaran dana desa.

Tabel 6 menunjukan nilai $F$ hitung sebesar 69,493 dengan nilai signifikansi sebesar 0,000 dan lebih kecil daripada tingkat signifikansi yang digunakan pada penelitian ini yaitu $5 \%$ atau 0,05 , maka dapat disimpulkan bahwa lingkungan pengendalian, penilaian resiko, kegiatan pengendalian, informasi dan komunikasi serta pemantauan secara simultan berpengaruh signifikan terhadap pelaksanaan anggaran dana desa.

\subsection{Uji Determinasi (Uji $R^{2}$ )}

Setelah variabel independen dinyatakan berpengaruh terhadap Perencanaan Anggaran Dana Desa (Y1) dan Pelaksanaan Anggaran Dana Desa (Y2), maka untuk melihat seberapa besar pengaruhnya dapat dilihat pada Tabel 7 dan Tabel 8. Hasil Uji Koefisien Determinasi perencanaan Anggaran Dana Desa (Y1), seberapa besar pengaruhnya disajikan pada Tabel 7. Sementara hasil Uji Koefisien Determinasi Pelaksanaan Anggaran Dana Desa (Y2) disajikan pada Tabel 8.

Tabel 7 Uji Koefisien Determinasi (Y1)

Model Summary

\begin{tabular}{ccccc} 
Model & R & R Square & Adjusted R Square & $\begin{array}{c}\text { Std.Error the } \\
\text { Estimate }\end{array}$ \\
\hline 1 &, $789^{\mathrm{a}}$ & 623 &, 613 &, 889 \\
\hline
\end{tabular}

a. Predictors: (Constant), Total_X5, Total_X2, Total_X4, Total_X3, Total_X1 
Tabel 8 Uji koefisien determinasi (Y2)

\begin{tabular}{ccccc}
\hline Model & $\mathbf{R}$ & Model Summary & Adjusted R Square & $\begin{array}{c}\text { Std. Error the } \\
\text { Estimate }\end{array}$ \\
\hline 1 &, $809^{\mathrm{a}}$ &, 655 &, 646 &, 854 \\
\hline
\end{tabular}

a. Predictors: (Constant), Total_X5, Total_X2, Total_X4, Total_X3, Total_X1

Setelah variabel independen dinyatakan berpengaruh terhadap perencanaan anggaran dana desa (Y1) dan pelaksanaan anggaran dana desa (Y2), seberapa besar pengaruhnya hasil perhitungan dengan menggunakan Statistical Program for Social Science (SPSS), dapat dijelaskan sebagai berikut:

1. Hasil uji koefisien determinasi perencanaan anggaran dana desa. Tabel 7 menunjukkan bahwa nilai Adjusted $R$ Square adalah 0,613 atau 61,3\%. Ini berarti bahwa variabel independen berupa lingkungan pengendalian, penilaian resiko, kegiatan pengendalian, informasi dan komunikasi serta pemantauan secara bersama-sama mempengaruhi variabel dependen perencanaan anggaran dana desa sebesar $61,3 \%$ sedangkan sisanya sebesar $38,7 \%$ dipengaruhi oleh faktor-faktor lain yang tidak diketahui dan tidak termasuk dalam analisis regresi penelitian ini.

2. Hasil uji koefisien determinasi pelaksanaan anggaran dana desa. Tabel 8 menunjukkan bahwa nilai Adjusted $R$ Square adalah 0,646 atau 4,6\%. Ini berarti bahwa variabel independen berupa lingkungan pengendalian, penilaian resiko, kegiatan pengendalian, informasi dan komunikasi serta pemantauan secara bersama-sama mempengaruhi variabel dependen pelaksanaan anggaran dana desa sebesar $64,6 \%$ sedangkan sisanya sebesar $35,4 \%$ dipengaruhi oleh faktor-faktor lain yang tidak diketahui dan tidak termasuk dalam analisis regresi penelitian ini.

\section{PEMBAHASAN}

Pengawasan intern merupakan salah satu bagian dari kegiatan pengendalian intern yang berfungsi melakukan penilaian independen atas pelaksanaan tugas dan fungsi instansi pemerintah. Moeller (2007) menyampaikan pendapat bahwa pengendalian intern dapat dilihat sebagai proses yang terintegrasi pada tindakan dan kegiatan yang dilakukan secara terus menerus oleh pimpinan dan seluruh pegawai untuk memberikan keyakinan memadai atas tercapainya tujuan organisasi melalui kegiatan yang efektif dan efisien, keandalan pelaporan keuangan, pengamanan aset negara, dan ketaatan terhadap peraturan perundangundangan yang dapat dilihat pada perencanaan dan pelaksanaan anggaran.

\subsection{Lingkungan Pengendalian, Penilaian Resiko, Kegiatan Pengendalian, Informasi dan Komunikasi dan Pemantauan Berpengaruh terhadap Perencanaan Anggaran Dana Desa}

Hasil penelitian menunjukan bahwa variabel lingkungan pengendalian, penilaian resiko, kegiatan pengendalian, informasi dan komunikasi serta pemantauan berpengaruh terhadap perencanaan anggaran dana desa. Hal ini ditujukan dengan besarnya nilai probabilitas sebesar 0,000 dengan taraf signifikansi $<0,05$. Artinya hipotesis kesebelas (H11-a) diterima dan dapat disimpulkan bahwa lingkungan pengendalian, penilaian risiko, kegiatan pengendalian, informasi dan komunikasi serta pemantauan berpengaruh secara simultan terhadap perencanaan anggaran dana desa. Semua unsur pengendalian SPIP yakni lingkungan pengendalian, penilaian resiko, kegiatan pengendalian, informasi dan komunikasi serta pemantauan pada pemerintah desa di Kecamatan Mentaya Hulu telah diimplementasikan dengan baik. Hal ini mengidikasikan bahwa implementasi SPIP memberikan kontribusi yang baik bagi pemerintah desa di Kecamatan Mentaya Hulu dalam menyusun perencanaan anggaran dana desa untuk pembangunan dan pemberdayaan masyarakat. Hipotesis yang menyatakan bahwa lingkungan pengendalian, penilaian resiko, kegiatan pengendalian, informasi dan komunikasi serta pemantauan secara bersama-sama (simultan) berpengaruh terhadap perencanaan anggaran dana desa dapat diterima.

\subsection{Lingkungan Pengendalian, Penilaian Resiko, Kegiatan Pengendalian, Informasi dan Komunikasi dan Pemantauan Berpengaruh terhadap Pelaksanaan Anggaran Dana Desa}

Hasil penelitian menunjukan bahwa variabel lingkungan pengendalian, penilaian resiko, kegiatan pengendalian, informasi dan komunikasi serta pemantauan berpengaruh terhadap pelaksanaan anggaran dana desa. Hal ini ditujukan dengan besarnya nilai probabilitas sebesar 0,000 dengan taraf signifikansi $<0,05$. Artinya hipotesis keduabelas (H12-b) diterima dan dapat disimpulkan bahwa lingkungan pengendalian, penilaian resiko, kegiatan pengendalian, informasi dan komunikasi serta pemantauan berpengaruh secara simultan terhadap pelaksanaan anggaran dana desa. SPIP berpengaruh positif terhadap pelaksanaan anggaran dana desa. Artinya semakin diterapkannya SPIP akan meningkatkan pelaksanaan anggaran dana desa. Kelima unsur SPIP tersebut mampu 
memberikan pengaruh yang signifikan terhadap pelaksanaan anggaran dana desa karena SPIP merupakan proses kegiatan audit, review, evaluasi, pemantauan, dan kegiatan pengawasan lain terhadap penyelenggaraan tugas dan fungsi organisasi dalam rangka memberikan keyakinan yang memadai bahwa kegiatan telah dilaksanakan sesuai dengan tolok ukur yang telah ditetapkan secara efektif dan efisien untuk kepentingan pimpinan dalam mewujudkan tata kepemerintahan yang baik. Dengan demikian, hipotesis yang menyatakan bahwa lingkungan pengendalian, penilaian resiko, kegiatan pengendalian, informasi dan komunikasi serta pemantauan secara bersama-sama (simultan) berpengaruh terhadap pelaksanaan anggaran dana desa dapat diterima.

\subsection{Implikasi Kebijakan}

Penelitian ini menunjukkan bahwa sistem pengendalian intern pemerintah (SPIP) dan COSO Framework memiliki pengaruh terhadap perencanaan dan pelaksanaan anggaran dana desa di Kecamatan Mentaya Hulu, Kabupaten Kotawaringin Timur. Pengaruh tersebut sangat dipengaruhi oleh sumber daya manusia yang menerapkan dan komitmen dalam menerapkan unsur-unsur SPIP. Implikasi pada kebijakan pemerintah daerah, untuk terus mempertahankan penerapan SPIP sehingga perencanaan dan pelaksanaan anggaran dana desa dapat berjalan dengan efektif. Diharapkan penelitian ini juga dapat mendorong pemerintah daerah agar lebih berkomitmen dalam penerapan SPIP dengan menyusun prosedurprosedur yang telah diterapkan menjadi sebuah pedoman/ kebijakan sehingga dapat menjadi acuan dalam penerapan SPIP serta meningkatkan peran pengawasannnya dalam penerapan SPIP sehingga dapat memberikan hasil yang optimal.

\section{KESIMPULAN DAN SARAN}

Berdasarkan analisis yang telah dilakukan disimpulkan bahwa SPIP berpengaruh secara simultan terhadap perencanaan dan pelaksanaan anggaran dana desa. SPIP berpengaruh positif terhadap pelaksanaan anggaran dana desa, artinya semakin diterapkannya SPIP, akan meningkatkan pelaksanaan anggaran dana desa. Hal ini menunjukkan bahwa Peraturan Pemerintah Nomor 60 Tahun 2008 telah dilaksanakan dengan baik. Pemerintah desa mampu melakukan proses identifikasi dan analisis risiko yang mungkin terjadi dalam proses perencanaan dan pelaksanaan anggaran dana desa sehingga dapat mengurangi resiko yang mungkin terjadi dalam perencanaan anggaran dana desa. Pemantauan diselenggarakan melalui kegiatan monitoring/kontrol pengelolaan rutin terkait dalam pelaksanaan tugas baik oleh atasan langsung maupun kontrol dalam bentuk koordinasi antar bidang untuk memberikan masukan.
Berdasarkan kesimpulan tersebut penelitian selanjutnya diharapkan dapat menambah jumlah sampel wilayah yang diteliti untuk memberikan gambaran secara komprehensif pengaruh penerapan SPIP terhadap perencanaan dan pelaksanaan anggaran dana desa. Tanya jawab atau wawancara dengan responden terkait dengan tema yang diteliti dapat dilakukan dalam studi pendahuluan sehingga kuesioner yang disusun menjadi lebih tejam. Selanjutnya, pemerintah daerah perlu mempertahankan sistem pengendalian dan diformalkan menjadi sebuah peraturan untuk menjadi pedoman dalam melakukan perencanaan dan pelaksanaan anggaran dana desa.

\section{DAFTAR PUSTAKA}

Atmadja, A.T. and Saputra, A.K., 2017. Pencegahan Fraud dalam Pengelolaan Keuangan Desa. Jurnal Ilmiah Akuntansi dan Bisnis, 12(2), 7-16.

Ghozali, I., 2016. Aplikasi analisis Multivariete dengan program IBM SPSS 23 (edisi 8). Cetakan ke VIII. Semarang: Badan Penerbit Universitas Diponegoro.

Herawati, T., 2014. Pengaruh Sistem Pengendalian Intern Terhadap Kualitas Laporan Keuangan (Survei Pada Organisasi Perangkat Daerah Pemda Cianjur). STARStudy \& Accounting Research, 11(1), 1-14.

Mutmainah, I. and Pramuka, B.A., 2017. Penerapan akuntabilitas pengelolaan dana desa dan Sistem Pengendalian Intern Pemerintah (SPIP) di Kecamatan Kedungwuni Kabupaten Pekalongan. Jurnal Ekonomi, Bisnis, dan Akuntansi, 19(4), 1-12.

Martini, R., Lianto, N., Hartati, S., Zulkifli, Z. and Widyastuti, E., 2019. Sistem Pengendalian Intern Pemerintah atas Akuntabilitas Pengelolaan Keuangan Dana Desa di Kecamatan Sembawa. Jurnal Akademi Akuntansi (JAA), 2(1), 106-123.

Moeller, R.R., 2007. COSO enterprise risk management: understanding the new integrated ERM framework. John Wiley \& Sons.

Norjani, 2019. Pemkab Kotim Tingkatkan Pembinaan Pengelolaan Keuangan Desa. Diakses dari: http:// kalteng.antaranews.com/berita/303387/pemkabkotimtingkatkan-pembinaan-pengelolaan-keuangandesa (15 September 2019).

Hindriani, N., Hanafi, I. and Domai, T., 2012. Sistem Pengendalian Intern Pemerintah (SPIP) Dalam Perencanaan dan Pelaksanaan Anggaran di Daerah (Studi Pada Dinas Kesehatan Kabupaten Madiun). WACANA, Jurnal Sosial dan Humaniora, 15(3), 1-9.

Peraturan Pemerintah No. 60 Tahun 2014 Tentang Dana Desa

Peraturan Menteri Desa No. 5 Tahun 2015 Tentang Pembangunan Daerah Tertinggal dan Transmigrasi.

Peraturan Pemerintah Nomor 8 Tahun 2016 tentang Dana Desa yang Bersumber dari Anggaran Pendapatan dan 
Belanja Negara.

Peraturan Pemerintah Nomor 60 Tahun 2008 tentang Sistem Pengendalian Intern Pemerintah

Peraturan Pemerintah Nomor 43 Tahun 2014 tentang Peraturan Pelaksanaan UU Nomor 6 Tahun 2014 tentang Desa.

Pamungkas, A., 2019. Pengaruh Penerapan Enterprise Risk Management (COSO) Terhadap Nilai Perusahaan: Studi Empiris pada Perusahaan Manufaktur yang Terdaftar di
BEl. Jurnal Akuntansi, 11(1), 12-21.

Ratag, W.A., Kumenaung, A.G. and Engka, D.S., 2021. Pengaruh Perencanaan Anggaran Terhadap Penyerapan Anggaran Di Lingkungan Iniversitas Sam Ratulangi. Jurnal Pembangunan Ekonomi dan Keuangan Daerah, 20(3), 78-91.

Safitri, R., 2015. Pengaruh Kompensasi Terhadap Loyalitas Karyawan PT. Putera Lautan Kumala Lines Samarinda. Jurnal Administrasi Bisnis, 3(3), 650-660. 